\title{
Early Archean inheritance in zircon from Mesozoic Dalongshan granitoids in the Yangtze Foldbelt of Southeast China
}

\author{
ZHANG Hong ${ }^{1}$, Zheng Yong-FeI ${ }^{2 *}$, ZHENG MAO-GoNG ${ }^{1}$ \\ and YENG JUN-LONG ${ }^{1}$ \\ Beijing Institute of Uranium Geology, P.O. Box 764, Beijing, China ${ }^{1}$ \\ and Geochemical Institute, Göttingen University, Goldschmidstr. 1, \\ D-3400 Göttingen, Germany²
}

(Received April 27, 1990; Accepted August 1, 1990)

\begin{abstract}
Zircon U-Pb isotopic data on the early Cretaceous Dalongshan granitoids in the Yangtze Foldbelt of Southeast China provides evidence for the incorporation of old Archean crustal material. The age of inherited radiogenic lead is determined by the three-dimensional U-Pb discordia plane method to be about $3330 \pm 180 \mathrm{Ma}$, indicating that the early Archean basement probably exists underneath the northwest part of the Yangtze Foldbelt. The nature of the source region of initial lead in the zircon demands that the Archean basement is responsible for a lower crust or a depleted mantle.
\end{abstract}

\section{INTRODUCTION}

$\mathrm{U}-\mathrm{Pb}$ zircon geochronology on young granitoids has often revealed the contribution of an old crustal component to the origin of the granitoids. There are many examples of intrusive granitoids containing old inherited radiogenic $\mathrm{Pb}$ in zircons which show an incomplete resetting of the $\mathrm{U}-\mathrm{Pb}$ systems during melting event. These include the Vire-Carolles granite from Normandy (Pastells, 1970), the Bergell granite from the southern Alps (Gulson and Krogh, 1973), the Idaho batholith (Grauert and Hofmann, 1973), the Labrador adamellites (Krogh and Davis, 1973), a number of Caledonian granites from Scotland and England (Pidgeon and Johnson, 1974; Pankhurst and Pidgeon, 1976; Pidgeon and Aftalion, 1978), the western Calicia granites from NW Spain (Kuijper et al., 1982), the Palung granite from Himalaya (Schärer and Allégre, 1983), the Tera and Finister granodiorites from the Berridale
Batholith (Williams et al., 1983), the Coast granitoids from Peninsular Malaysia (Liew and McCulloch, 1985), the Berkshire granite from the Connectinut (Zartman et al., 1986), the Narragansett Pier granite from New England (Zartman and Hermes, 1987), and the Tertiary granite from the Himalaya (Copeland et al., 1988). Even zircons from volcanics were detected to contain the inherited radiogenic $\mathrm{Pb}$ signature (e.g., Peucat et al., 1986).

The presence of the inherited radiogenic $\mathrm{Pb}$ in zircons is evidence that old crustal components have been incorporated into young granitoid magmas. In cases where the source zircons have not suffered extensive pre- and postemplacement $\mathrm{Pb}$ loss, inheritance ages allow to estimate the ages of the zircon-bearing protoliths of the young granitoids. In this context, the determination of inheritance ages can shed light on the growth and evolution of continental crust. There is substantial evidence for the episodic growth of continental crust. The ques- 
tions are when the crustal addition was made in a given region and how much new crust was formed during each episode. The present study presents $\mathrm{U}-\mathrm{Pb}$ isotopic data for zircons from the early Cretaceous Dalongshan granitoid massif in the Yangtze Foldbelt of Southeast China. An old Archean crustal material is indicated by zircon $\mathrm{U}-\mathrm{Pb}$ inheritance age, implying that the early Archean basement probably exists in this region.

\section{Geological Setring}

East China is divided into two large cratons: the Sino-Korean craton in the north and the Yangtze craton in the south (Zhang et al., 1984). Archean basements have been documented to occur in the Sino-Korean craton ( Jahn and Zhang, 1984; Liu et al., 1985; Huang et al., 1986; Jahn et al., 1987; Liu et al., 1989). The Yangtze craton has been dated to contain Proterozoic to late Archean basements (Zhu et al., 1979; Chen et al., 1985; Li et al. 1989).

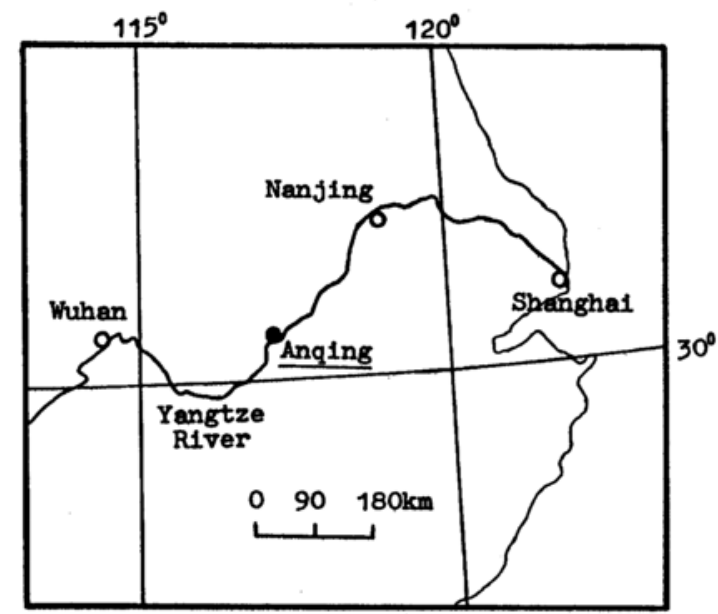

Fig. 1. Sketch map showing locality of the Anqing City by the Yangtze River in Sourtheast China.

The Yangtze Foldbelt is between the SinoKorean craton and the Yangtze craton and strikes northeast along the Yangtze River (Figs. 1 and 2). The Dalongshan granitoid massif of

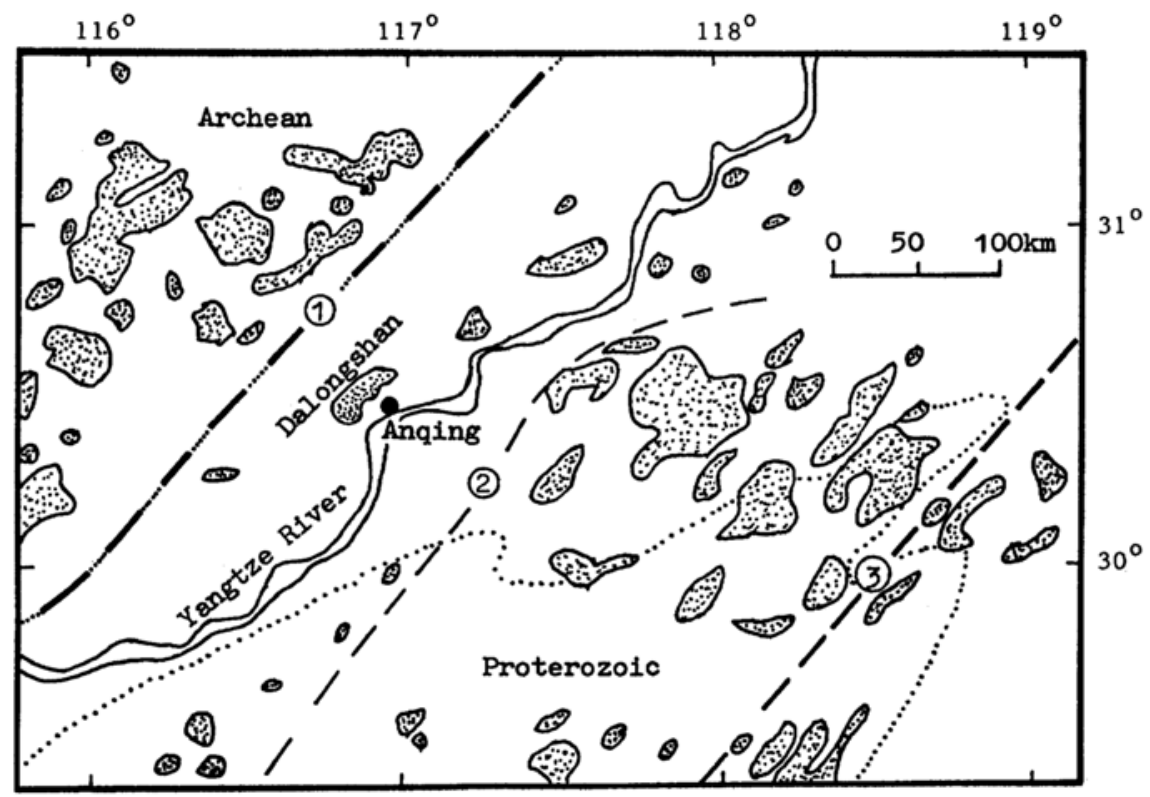

Fig. 2. Schematic geological map of the Yangtze Foldbelt in sourthern Anhui Province showing the distributions of intermediate to acidic intrusions and Precambrian rocks (modified after Geochemical Institute of Academia Sinica, 1979). The stippled patterns indicate granitoid intrusions. The dashed lines indicate major faults: 1-the Tancheng-Lujiang Fault, 2-the Yangtze Fault, 3-the Guangde-Dexing Fault. The dotted line from the sourthwest (coincident with the Tancheng-Lujiang Fault) to the sourtheast represents the known limits of Archean and Proterozoic basements, respectively. 


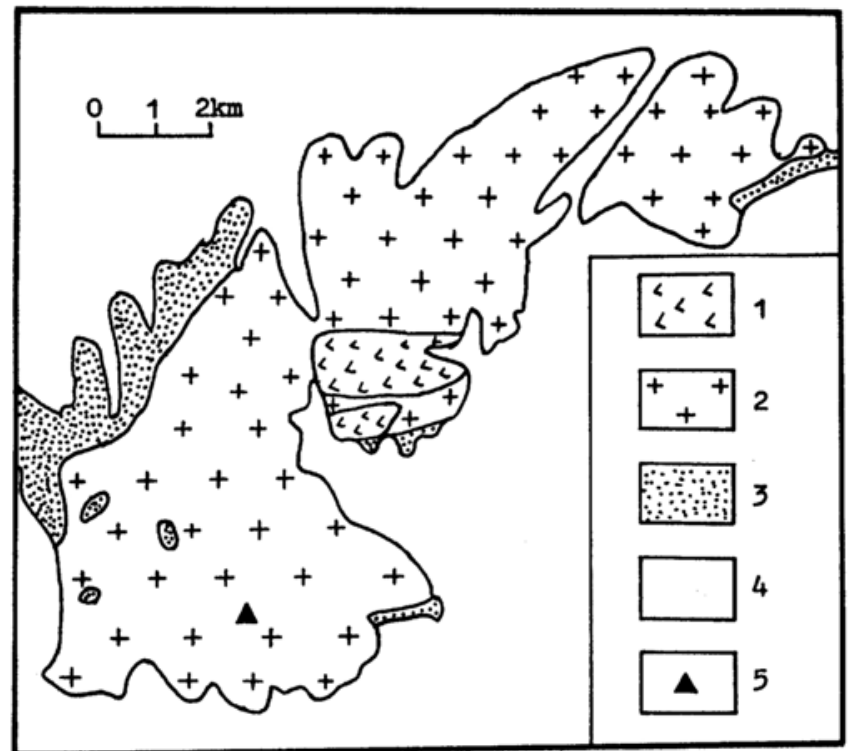

Fig. 3. Sketch map of the Dalongshan granitoid massif. 1-early stage quartz syenite, 2-late stage alkalifeldspar granite, 3-Jurassic feldspar-quartz sandstone, 4-Quaternary cover, 5-sampling site.

concern in the present study is located in the north of the Yangtze River. Tectonically it is located between the Tancheng-Lujiang Fault and the Yangtze Fault. The age of basements beneath the Yangtze Foldbelt is uncertain as the Archean occurs to the northwest and the Proterozoic to late Archean to the southeast. Mesozoic sedimentary and volcanic units are widespread in this Foldbelt.

The Dalongshan granitoid massif is located near Anqing City, Anhui Province (Fig. 2). It is a composite intrusion exposed over approximately $90 \mathrm{~km}^{2}$ (Fig. 3). The magmas were emplaced into the Jurassic feldspar-quartz sandstones. The early stage intrusion was quartz syenites; these rocks were in turn intruded by a late stage alkali-feldspar granite. The detailed petrographic and geochemical characteristics of the granitoids have been described by Zhai (1985). $\mathrm{Rb}-\mathrm{Sr}$ whole-rock dating shows that the quartz syenites have an isochron age of $136 \pm 5 \mathrm{Ma}$ with an initial ${ }^{87} \mathrm{Sr} /{ }^{86} \mathrm{Sr}$ ratio of $0.7071 \pm 0.0008$, and that the alkali-feldspar granite has an isochron age of $117 \pm 4 \mathrm{Ma}$ with an initial ${ }^{87} \mathrm{Sr} /{ }^{86} \mathrm{Sr}$ ratio of $0.7082 \pm 0.0011$ (Zhang, 1988).
Inasmuch as the Dalongshan massif is associated with striking-slip faulting (anoroganic) and has alkaline geochemical features $\left(\mathrm{Na}_{2} \mathrm{O}+\right.$ $\mathrm{K}_{2} \mathrm{O}>9 \%$ ), Zhai (1985) identified the Dalongshan granitoids as the A-type granites as defined by Loiselle and Wones (1979). In the light of feldspar $\mathrm{Pb}$ isotope investigation Zhang (1988) suggested that a lower crustal material was involved in the genesis of the granitoids.

\section{Analytical Methods}

The rock samples were collected from the late stage intrusion of the Dalongshan granitoids (Fig. 3). After crushing and grinding the samples, heavy minerals were separated using a Wilfley table, heavy liquid and magnetic methods. The recovered zircons were sieved into size fractions and split further according to their magnetic susceptibility. Seven zircon fractions were separated for the sample D103-2, in which fraction 7 has the same size and magnetic susceptibility as fraction 3. After hand picking under a binocular microscope to $99 \%$ purity, all separates were cleaned by repeated rinsing with 
warm $\mathrm{HNO}_{3}$, but fractions 1 to 6 of the sample D103-2 in an ultrasonic bath. The size fractions were then dissolved, and $\mathrm{Pb}$ and $\mathrm{U}$ were extracted following the methods described by Krogh (1973).

$\mathrm{Pb}$ isotopic ratios were measured on a MAT261 thermion mass spectrometer in Beijing Institute of Uranium Geology. All the $\mathrm{Pb}$ isotopic ratios have been normalized to the NBS SRM981 standard composition using a discrimination factor of $0.12 \%$ per mass unit. Correction for the laboratory $\mathrm{Pb}$ background effect differentiation were determined by the method reported by $\mathrm{Li}$ and $\mathrm{Xu}$ (1987). Uncertainties of $\pm 1.0 \%$ and $\pm 0.1 \%(1 \sigma)$ are estimated for $\mathrm{Pb} / \mathrm{U}$ and ${ }^{207} \mathrm{~Pb} /{ }^{206} \mathrm{~Pb}$ ratios, respectively.

\section{Results}

The results of ten zircon $\mathrm{U}-\mathrm{Pb}$ isotopic analysis are given in Table 1. Uranium concentration is lower in the fraction of low magnetic susceptibility than that of high susceptibility. Additionally uranium concentration increases generally with decreasing grain size.

Minimum ${ }^{206} \mathrm{~Pb} /{ }^{204} \mathrm{~Pb}$, ratio for the investigated samples is as low as 46.262 , indicating that common (initial) lead component is appreciable and that errors due to uncertainty in correcting for it are significant. In general, for those samples with low ${ }^{206} \mathrm{~Pb} /{ }^{204} \mathrm{~Pb}$ ratio (e.g., $<100$ ), knowledge of the common lead isotopc composition is critical, especially for ${ }^{207} \mathrm{~Pb} /{ }^{204} \mathrm{~Pb}$. The detection of inherited radiogenic lead in the $\mathrm{U}-\mathrm{Pb}$ system of zircons is usually carried out with the aid of a Wetherill's (1956) concordia diagram. In this respect, the correction for the proper initial $\mathrm{Pb}$ isotope composition responsible for a previous event at time $t_{1}$ is of crucial importance in using the two-stage $\mathrm{U}-\mathrm{Pb}$ episodic model for probing early events (Zheng, 1990). The U-Pb isotopic data for a suite of cogenetic samples may be corrected for any initial $\mathrm{Pb}$ isotopic composition other than that at time $t_{2}$ (later event). And the data may or may not form a linear array in the conventional concordia diagram. In most cases, the lower (younger) intersection age $\left(t_{2}\right)$ is close to the true age of the last stage $\mathrm{U}-\mathrm{Pb}$ episodic event. But whether the upper (older) intersection age $\left(t_{1}\right)$ is realistic or not is subject to uncertainties of the correction for initial lead. To eliminate the effect of the unknown common lead correction, a three-dimensional U-Pb discordia plane method

Table 1. Zircon $\mathrm{U}-\mathrm{Pb}$ isotopic data on the later stage intrusion of the Dalongshan granitoids in the Yangtze Foldbelt of South China

\begin{tabular}{|c|c|c|c|c|c|c|c|c|c|c|c|}
\hline \multirow{3}{*}{ No. } & \multirow{3}{*}{$\begin{array}{l}\text { Sample } \\
\text { number }\end{array}$} & \multirow{3}{*}{$\begin{array}{l}\text { Fraction } \\
\text { (mesh) }\end{array}$} & \multirow{2}{*}{\multicolumn{2}{|c|}{ Concentration }} & \multicolumn{4}{|c|}{ Isotopic ratios } & \multicolumn{3}{|c|}{ Model ages $(\mathrm{Ma})^{*}$} \\
\hline & & & & & ${ }^{206} \mathrm{~Pb}$ & ${ }^{206} \mathrm{~Pb}$ & ${ }^{235} \mathrm{U}$ & ${ }^{204} \mathrm{~Pb}$ & ${ }^{206} \mathrm{~Pb}$ & ${ }^{207} \mathrm{~Pb}$ & ${ }^{207} \mathrm{~Pb}$ \\
\hline & & & $\mathrm{U}$ (ppm) & $\mathrm{Pb}(\mathrm{ppm})$ & $\overline{{ }^{204} \mathrm{~Pb}}$ & $\overline{{ }^{207} \mathrm{~Pb}}$ & $\overline{{ }^{207} \mathrm{~Pb}}$ & ${ }^{207} \mathrm{~Pb}$ & $\overline{{ }^{238} U}$ & $\overline{{ }^{235} U}$ & $\overline{{ }^{206} \mathrm{~Pb}}$ \\
\hline 1 & D103-2 & $\begin{array}{l}+140, \text { low } \\
\text { susceptib. }\end{array}$ & 501.74 & 13.84 & 318.175 & 10.272 & 3.7716 & 0.032285 & 119 & 126 & 265 \\
\hline 2 & D103-2 & +140 , high & 634.49 & 17.58 & 226.061 & 8.433 & 3.1885 & 0.037304 & 113 & 123 & 332 \\
\hline 3 & D103-2 & $\begin{array}{c}-140,+180 \\
\text { low }\end{array}$ & 520.21 & 13.32 & 725.775 & 12.381 & 4.6788 & 0.017060 & 119 & 148 & 637 \\
\hline 4 & D103-2 & $\begin{array}{c}-140,+180 \\
\text { high }\end{array}$ & 708.95 & 19.80 & 241.943 & 8.419 & 3.1928 & 0.034797 & 113 & 137 & 571 \\
\hline 5 & D103-2 & $\begin{array}{c}-180,+220 \\
\text { low }\end{array}$ & 535.66 & 13.37 & 700.022 & 13.311 & 5.1194 & 0.019015 & 117 & 131 & 387 \\
\hline 6 & D103-2 & $\begin{array}{c}-180,+220 \\
\text { high }\end{array}$ & 704.37 & 20.14 & 229.358 & 8.498 & 3.1162 & 0.037053 & 116 & 130 & 386 \\
\hline 7 & D103-2 & $\begin{array}{l}\text { No. } 3 \text { but no } \\
\text { ultrasonic } \\
\text { bathing }\end{array}$ & 608.69 & 31.94 & 62.062 & 3.264 & 0.8869 & 0.052600 & 120 & 191 & 1195 \\
\hline $\begin{array}{l}8 \\
9\end{array}$ & $\begin{array}{l}\text { D029 } \\
\text { D041 }\end{array}$ & $\begin{array}{l}+250 \\
+250\end{array}$ & $\begin{array}{l}333 \\
308\end{array}$ & $\begin{array}{l}18.41 \\
26.07\end{array}$ & $\begin{array}{l}68.051 \\
46.262\end{array}$ & $\begin{array}{l}3.696 \\
2.667\end{array}$ & $\begin{array}{l}0.8769 \\
0.4879\end{array}$ & $\begin{array}{l}0.054307 \\
0.057652\end{array}$ & $\begin{array}{l}142 \\
152\end{array}$ & $\begin{array}{l}169 \\
198\end{array}$ & $\begin{array}{l}554 \\
789\end{array}$ \\
\hline 10 & D014 & +250 & 463 & 25.28 & 88.177 & 4.602 & 1.0934 & 0.052185 & 154 & 163 & 293 \\
\hline
\end{tabular}

*calculated using the average isotope ratio of lead from feldspars in the Dalongshan granitoids for the correction of common lead: ${ }^{206} \mathrm{~Pb} /{ }^{204} \mathrm{~Pb}=18.37$ and ${ }^{207} \mathrm{~Pb} /{ }^{204} \mathrm{~Pb}=15.52$ (Zhang, 1988) 


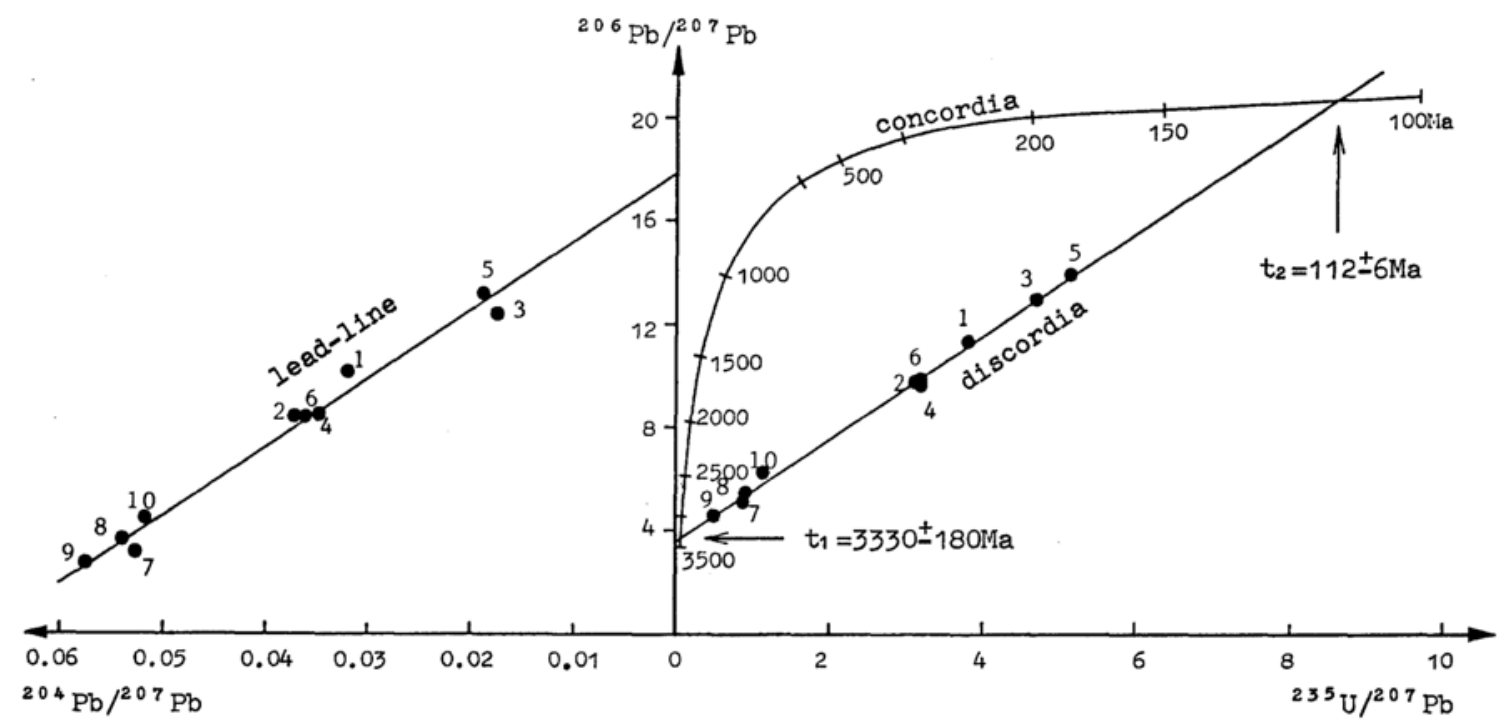

Fig. 4. Three-dimensional ${ }^{206} \mathrm{~Pb} /{ }^{207} \mathrm{~Pb}$ versus ${ }^{235} \mathrm{U} /{ }^{207} \mathrm{~Pb}$ and ${ }^{204} \mathrm{~Pb} /{ }^{207} \mathrm{~Pb}$ plot for zircons from the late stage intrusion of the Dalongshan granitoids in the Yangtze Foldbelt of Southeast China.

described by Zheng (1990) is applied in this study. This method uses only the directly measured isotopic ratios ${ }^{235} \mathrm{U} /{ }^{207} \mathrm{~Pb},{ }^{206} \mathrm{~Pb} /{ }^{207} \mathrm{~Pb}$ and ${ }^{204} \mathrm{~Pb} /{ }^{207} \mathrm{~Pb}$ to yield two ages $t_{1}$ and $t_{2}$ responsible for two episodic events. It does not require any knowledge of the isotopic ratios of initial lead for correction, provided that only one type of initial $\mathrm{Pb}$ isotope composition is justified for the investigated samples.

A least-squares fit to the data given in Table 1 yields the following parameters:

$$
\begin{aligned}
& a=1.9906 \pm 0.1094 \\
& b=3.5660 \pm 0.2053 \\
& c=-32.20 \pm 3.28 \\
& t_{1}=3330 \pm 180 \mathrm{Ma} \\
& t_{2}=112 \pm 6 \mathrm{Ma} .
\end{aligned}
$$

The calculated coefficient of polycorrelation is 0.9971 , indicating that the data points all fall on the fitted discordia plane within the estimated analytical errors. A modified discordia line is drawn by taking the $\left({ }^{206} \mathrm{~Pb} /{ }^{207} \mathrm{~Pb}\right)$ $-c\left({ }^{204} \mathrm{~Pb} /{ }^{207} \mathrm{~Pb}\right)$ for ordinate and the ${ }^{235} \mathrm{U} /{ }^{207} \mathrm{~Pb}$ for abscissa respectively, as depicted in the right of Fig. 4; a lead-line is drawn in the left of Fig. 4, using the isotopic data uncorrected.

\section{Discussion}

The good linear distribution of discordia data points in the right of Fig. 4 allows us to derive age information which has geological significance. The fractions 1,3 and 5 with low magnetic susceptibility are closer to the upper (younger) intersection than the fractions 2, 4 and 6 with high susceptibility; the smaller the fraction with the low susceptibility, the closer to the younger intersection their $\mathrm{U}-\mathrm{Pb}$ discordia data points. This can be attributed to the loss of inherited lead component caused by the ultrasonic bathing. The principal benefit of the ultrasonic bathing is that it induces a good linear distribution of discordia data points in the concordia diagram and therefore it enables us to derive age information of geochronological significance.

The obtained $t_{2}$ age is $112 \pm 6 \mathrm{Ma}$, which can be reasonably interpreted as the closure age of $\mathrm{U}-\mathrm{Pb}$ isotopic system during crystallization of the late stage granitoid magma. This age is well comparable with the $\mathrm{Rb}-\mathrm{Sr}$ isochron age of $117 \pm 4 \mathrm{Ma}$ for the late stage alkali-feldspar granite.

The $t_{1}$ age of $3330 \pm 180 \mathrm{Ma}$ may represent 
the age of inherited radiogenic lead component in the zircons that has incorporated into the granitoid magma. This assumes that the discordia is an undisturbed mix of the inherited component with a young magmatic component at time $\sim 112 \mathrm{Ma}$. In fact, model age pattern of $t\left({ }^{206} \mathrm{~Pb} /{ }^{238} \mathrm{U}\right)<t\left({ }^{207} \mathrm{~Pb} /{ }^{235} \mathrm{U}\right)<t\left({ }^{207} \mathrm{~Pb} /{ }^{206} \mathrm{~Pb}\right)$ in Table 1 and the lead-line with an intercept out of concordance in the left of Fig. 4 indicate the existence of inherited radiogenic lead in the zircons. The presence of inherited radiogenic lead component indicates that early Archean crustal material has been incorporated into the Mesozoic granitoids. Although the old component may have suffered $\mathrm{Pb}$ loss (or $\mathrm{U}$ gain) before it was incorporated into the magma, the good discordia plane is suggestive of that the $t_{1}$ age can provide a reliable age of the old lead component.

The basement of $c a$. $3330 \mathrm{Ma}$ has been reported to exist in the Sino-Korean craton. Using the single zircon stepwise evaporation technique, Liu et al. (1989) acquired an U-Pb age of 3.3 Ga for a zircon sample from Archean gneiss in the craton. This age is the oldest zircon age so far found in China. The consistent Sm-Nd isochron ages of $3.5 \mathrm{Ga}$ were obtained by Huang et al. (1986) and Jahn et al. (1987) for the Archean amphibolites from eastern Hebei Province within the craton. The present result indicates that the early Archean basement could be extended southwards to the northern part of the Yangtze Foldbelt adjacent to the Sino-Korean craton. Because the younger intersection age of the modified discordia from the present zircon $\mathrm{U}-\mathrm{Pb}$ data is in good agreement with the wholerock $\mathrm{Rb}-\mathrm{Sr}$ isochron age of the same intrusion, we can consider the older intersection age of $c a$. $3330 \mathrm{Ma}$ as the age of basement which could exist beneath the Yangtze Foldbelt.

The question of the origin of the inherited lead in the zircons is intimately related to the origin of the granitoids themselves. The old component could be derived from wallrocks stoped off during magma emplacement or they could have survived from the original source material of the granitoid magma. The proportion of the old inherited lead in the zircons must be quite high to account for the spread of the discordia data points on the concordia plot. A high degree of assimilation can explain the observed zircon $\mathrm{U}-\mathrm{Pb}$ systematics. However, the Dalongshan granitoids intrude into Mesozoic volcanosedimentary rocks at shallow levels. This geological environment may not be favorable for the wall-rock assimilation at shallow depths, but partial melting or assimilation of deep Precambrian basement rocks can be considered as the source of the inherited radiogenic lead. The old lead could also be contained in old zircons which were abundantly present in the source region of the granitoid magma and were incorporated without complete dissolution during partial melting. In either case, the $t_{1}$ age of $c a$. $3330 \mathrm{Ma}$ represents a real isotopic event and the old lead could have been derived from such a $c a .3 .3 \mathrm{Ga}$ old Archean basement.

The position of the zircon $\mathrm{U}-\mathrm{Pb}$ data points on the discordia cannot be simply used to provide quantitative estimates of the proportion of old-inherited to newly-formed radiogenic lead component without taking into account: (1) the complexity of the inherited radiogenic lead, (2) the nature and degree of isotopic discordance sustained by the inherited lead before and during crystallization of the granitoid magma, and (3) the magnetic susceptibility of inherited zircon relative to newly-formed zircon to post granitoid isotopic disturbance.

Within the framework of a restricted $\mathrm{U}-\mathrm{Pb}$ three-stage model (Ulrych, 1969), it is calculated that the investigated zircons have identical initial $\mathrm{Pb}$ isotope ratios ${ }^{206} \mathrm{~Pb} /{ }^{204} \mathrm{~Pb}=10.63$ and ${ }^{207} \mathrm{~Pb} /{ }^{204} \mathrm{~Pb}=12.01$ at time $t_{1}=3330 \mathrm{Ma}$, and that original system had a ${ }^{238} U /{ }^{204} \mathrm{~Pb}$ ratio $\left(\mu_{1}\right.$ value) of 3.73 for time interval from $t_{0}$ to $t_{1}$, given that we take the meteoritic parameters determined by Tatsumoto et al. (1973) for starting conditions (i.e., $\alpha_{0}=9.307, \beta_{0}=10.294$ and $t_{0}=4.57 \mathrm{Ga}$ ). This calculation has to require that the early Archean basement originated from a primitive mantle with a $\mu$ value of about 3-4. Such a low $\mu$ value conflicts with the current knowledge of the primitive mantle $\mu$ values. 
Alternatively, in view of the complex history experienced by the mantle before $4 \mathrm{Ga}$ ago, an extended three-stage episodic model for $\mathrm{U}-\mathrm{Pb}$ isotopic evolution may be more appropriate, in which case the starting parameters assigned by Zartman and Haines (1988) for Version IV of plumbotectonic model can be utilized (i.e., $\alpha_{0}=10.06, \beta_{0}=11.40$ and $t_{0}=4.2 \mathrm{Ga}$ ). Then it is obtained that the initial $\mathrm{Pb}$ isotope ratios at time $t_{1}=3330 \mathrm{Ma}$ are $\alpha_{1}=10.62$ and $\beta_{1}=12.01$ and that the $\mu_{1}$ value is 2.33 .

In either case, the calculated initial $\mathrm{Pb}$ isotope ratios are identical and the $\mu_{1}$ values are considerably low. The low $\mu_{1}$ values require a $\mathrm{U} / \mathrm{Pb}$-depleted reservoir for the source region of the initial lead incorporated into the zircons at the time $c a$. $3.3 \mathrm{Ga}$. Lower crust (or depleted mantle) is a probable candidate for the reservoir because only it has $\mu$ values lower than both primitive mantle and upper crust (O'Nions et al., 1979; Allégre et al., 1988; Zartman and Haines, 1988). In term of a U-Pb budget for various terrestrial reservoirs Zindler and Hart (1986) have estimated a mean $\mu=3.8$ (range from 1 to 9 ) for the lower crust. The depletion of $U$ in the lower crust relative to $\mathrm{Pb}$ and its concentration into the upper crust are well exemplified by the highgrade Archean metamorphic terranes (e.g., Moorbath et al., 1969; Black et al., 1971). Such internal differentiation of the continental crust has left the lower crust with $\mathrm{U} / \mathrm{Pb}$ ratios lower than the upper crust and the primitive mantle. In addition, the lowest $\mu$ values measured on MORB glasses are about 5 (Cohen et al., 1980). Neither seawater alteration nor partial melting can make $\mu$ values decrease (Allégre et al., 1988). Therefore, the lower crust (or depleted mantle) could have $\mu$ values lower than 5 due to the $\mathrm{U} / \mathrm{Pb}$ differentiation. Accordingly the lower crust (or depleted mantle) can be reasonably responsible for the $\mathrm{U} / \mathrm{Pb}$-depleted reservoir required by the isotopic composition of initial lead in the zircons. This argument is well comparable not only with the results from the feldspar $\mathrm{Pb}$ isotope data on the Dalongshan granitoids by Zhang (1988), but also with the positive $\varepsilon_{\mathrm{Nd}}(T)$ values of +2.7 to +3.3 for the Archean am- phibolites from the eastern Hebei Province by Huang et al. (1986) and Jahn et al. (1987). Recent works on anoroganic granites suggest that they may form from primary magmas produced by partial melting of relatively anhydrous lower crustal source rocks (e.g., Barker et al., 1975; Collins et al., 1982; Anderson, 1983; Jackson et al., 1984). Furthermore, if the formation of lower crust was related to the extraction of sialic upper crustal material from the primitive mantle, the $\mathrm{U}-\mathrm{Pb}$ isotope data of the Dalongshan granitoids lend support to the assumption by Jahn et al. (1987) based on the Sm-Nd isotope data of the Archean amphibolites that the existence of the sialic crust can be looked back before $4 \mathrm{Ga}$ ago.

The $\mu_{2}$ values for time interval from $t_{1}$ and $t_{2}$ can be further calculated and $\mathrm{U} / \mathrm{Pb}$ differentiation factor is then given by $f_{1}=\mu_{1} / \mu_{2}$ at $t_{1}$ and $f_{2}=\mu_{2} / \mu_{3}$ at $t_{2}$ (where $\mu_{2}$ and $\mu_{3}$ are responsible for the ${ }^{238} \mathrm{U} /{ }^{204} \mathrm{~Pb}$ ratios at time $t_{2}$ and the present day, respectively). The obtained $\mu_{2}$ values are $15-84, f_{1}$ values are $0.03-0.25$ and $f_{2}=0.0013-0.02$ for the zircons from the Dalongshan granitoids, indicating an enrichment of uranium relative to lead at the two episodic events. The $\mu_{2}$ values are so scattered that $\mathrm{a} \mathrm{Pb}-\mathrm{Pb}$ secondary isochron would not be yielded even if the lead isotope ratios are corrected back to those at time $t_{2}=112 \mathrm{Ma}$.

\section{Conclusions}

Involvement of early Archean crustal material in the formation of the Mesozoic Dalongshan granitoids is indicated by the inherited radiogenic lead in zircons. The $t_{1}$ age of $3330 \mathrm{Ma}$ defines the formation age of an old crust from which the inherited radiogenic lead was incorporated. This points to the presence of early Archean rocks at the depth at which the granitoid magma was derived or assimilated. The northern part of the Yangtze Foldbelt is probably underlain by the Archean basement, and Proterozoic basements occur in the southern part of this Foldbelt. The nature of the initial $\mathrm{U}-\mathrm{Pb}$ isotope system in the zircons indicates that 
the early Archean basement is responsible for the lower crust in this region.

Acknowledgments-The authors wish to thank Prof. Zhu Jie-Chen, Drs. Zhao Ya-Dong, Xue Li-Li and Gao Ding-Shun for their assistance during this work. Discussion with Drs. K. Friese and K. Mengel is greatly appreciated. The manuscript has benefited from constructive comments by two anonymous reviewers and from supportive editing by Dr. Y. Matsuhisa.

\section{REFERENCES}

Allégre, C. J., Lewin, E. and Dupré, B. (1988) A coherent crust-mantle model for the uraniumthorium-lead isotopic system. Chem. Geol. 70, 211234.

Anderson, J. L. (1983) Proterozoic anoroganic granite plutonism of North America. Proterozoic Geology ed. L. G. Medaria, C. W. Byers, D. M. Mickelson and W. C. Shanks, (Geol. Soc. Am. Mem. 161) 133-154.

Barker, F., Wones, D. R., Sharp, W. N. and Desborough, G. A. (1975) The Pikes Peak Batholith, Colorade Front Range, and a model for the origin of the gabbro-anorthosite-syenitepotassic granite suite. Precambrian Res. 2, 97-160.

Black, L. P., Gale, N. H., Moorbath, S. and Pankhurst, R. J. (1971) Isotopic dating of very early Precambrian amphibolite facies gneisses from the Godthaab district, West Greenland. Earth Planet. Sci. Lett. 12, 245-259.

Chen, J.-F., Folland, K. A. and Zhow, T.-X. (1985) Mesozoic granitoids of the Yangtze Foldbelt, China: isotopic constraints on the magma sources. The Crust-The Significance of Granite-Gneisses in the Lithosphere eds. L.-R. Wu, T.-M. Yang, J. Didier and S. S. Augustithis, Theophrastus Publications S. A., Athens, 217-237.

Cohen, R. S., Evensen, N. M., Hamilton, P. J. and O'Nions, R. K. (1980) U-Pb, Sm-Nd and Rb-Sr systematics of mid-ocean ridge basalt glasses. Nature 283, 149-153.

Collins, W. J., Beams, S., White, A. J. R. and Chappell, B. W. (1982) Nature and origin of A-type granites with particular reference to sourtheastern Australia. Contrib. Mineral. Petrol. 780, 189-200.

Copeland, P., Parrish, R. R. and Harrison, T. M. (1988) Identification of inherited radiogenic $\mathrm{Pb}$ in monazite and its implications for $\mathrm{U}-\mathrm{Pb}$ systematics. Nature 333, 760-763.

Geochemical Institute of Academia Sinica (1979) Geochemistry of Granitoids in Sourth China. Science Press, Beijing, 421 pp (Chinese).
Grauert, B. and Hofmann, A. (1973) Old radiogenic $\mathrm{Pb}$ component in zircons from the Idaho Batholith and its metasedimentary aureole. Carnegie Inst. Wash. Yearbk. 72, 297-299.

Gulson, B. L. and Krogh, T. E. (1973) Old lead component in the young Bergell Massif, Southeast Swiss Alps. Contrib. Mineral. Petrol. 40, 239-252.

Huang, X., Bi, Z.-W. and Depaolo, D. J. (1986) Sm$\mathrm{Nd}$ isotope stuy of early Archean rocks, Qianan, Hebei Province, China. Geochim. Cosmochim. Acta 50, 625-631.

Jackson, N. J., Walsh, J. N. and Pegran, E. (1984) Geology, geochemistry and petrogenesis of the late Precambrian granitoids in the Central Hijaz Region of the Arabian Shield. Contrib. Mineral. Petrol. 87, 205-219.

Jahn, B.-M., Auvray, B., Cornichet, J., Bai, Y.-L., Shen, Q.-H. and Liu, D.-Y. (1987) 3.5 Ga old amphibolite from eastern Hebei Province, China: field occurrence petrography, Sm-Nd isochron age and REE geochemistry. Precambrian Res. 34, 311-346. Jahn, B.-M. and Zhang, Z.-Q. (1984) Radiometric ages ( $\mathrm{Rb}-\mathrm{Sr}, \mathrm{Sm}-\mathrm{Nd}, \mathrm{U}-\mathrm{Pb})$ and REE geochemistry of Archaean granulite gneisses from eastern Hebei Province, China. Archaean Geochemistry ed. A. Kröner, Springer-Verlag, Berlin Heidelberg, 204-234.

Krogh, T. E. (1973) A low-contamination method for hydrothermal decomposition of zircon and extraction of $\mathrm{U}$ and $\mathrm{Pb}$ for isotopic age determination. Geochim. Cosmochim. Acta 37, 485-494.

Krogh, T. E. and Davis, G. L. (1973) The significance of inherited zircons on the age and origin of igneous rocks-an investigation of the ages of the Labrador Adamellites. Carnegie Inst. Wash. Yearbk. 72, 610613.

Kuijper, R. P., Priem, H. N. A. and Den Tex, E. (1982) Late-Archaean-early Proterozoic source ages of zircons in rocks from the Paleozoic Orogan of western Galicia, NW Spain. Precambrian Res. 19, 1-29.

Li, X.-H., Tatsumoto, M. and Premo, W. R. (1989) Age and origin of the Tanghu granite, Southeast China: results from $\mathrm{U}-\mathrm{Pb}$ single zircon and $\mathrm{Nd}$ isotopes. Geology 17, 395-399.

Li, X.-B. and Xu, R.-H. (1987) Modern analytical methods for $\mathrm{U}-\mathrm{Pb}$ dating of zircons. The Annals of the Beijing Institute of Uranium Geology 110-115 (Chinese).

Liew, T. C. and McCulloch, M. T. (1985) Genesis of granitoid batholiths of Peninsular Malaysia and implications for models of crustal evolution: evidence from a $\mathrm{Nd}-\mathrm{Sr}$ isotopic and $\mathrm{U}-\mathrm{Pb}$ zircon study. Geochim. Cosmochim. Acta 49, 587-600.

Liu, D.-Y., Page, R. W., Composton, W. and Wu, 
J.-S. (1985) U-Pb zircon geochronology of late Archaean metamorphic rocks in the TaihangshanWutaishan area, North China. Precambrian Res. 27, 85-109.

Liu, D.-Y., Shen, Q.-H., Jahn, B.-M. and Auvray, B. (1989) U-Pb geochronology by the single zircon stepwise evaporation method: case studies on the Archean rocks from the Sino-Korean craton. Terra Abstract 1, 351.

Loiselle, M. C. and Wones, D. R. 81979) Characteristics and origin of anoroganic granites. Geol. Soc. Am. Abst. Prog. 11, 468.

Moorbath, S., Welke, H. and Gale, N. H. (1969) The significance of lead isotope studies in ancient highgrade metamorphic basement complexes, as exemplified by the Lewisian rocks of Northwest Scotland. Earth Planet. Sci. Lett. 6, 245-256.

O'Nions, R. K., Evensen, N. M. and Hamilton, P. J. (1979) Geochemical modelling of mantle differentiation and crustal growth. J. Geophys. Res. 84, 60916101.

Pankhurst, R. J. and Pidgeon, R. T. (1976) Inherited isotope systems and the source region prehistory of early Caledonian granites in the Dalradian series of Scotland. Earth Planet. Sci. Lett. 31, 55-68.

Pastells, P. (1970) U-Pb radioactive ages of monazite and zircon from the Vire-Carolles Granite (Normandy): a case of zircon-monazite discrepancy. Ecl. Geol. Helv. 63, 231-237.

Peucat, J.-J., Paris, F. and Chalet, M. (1986) U-Pb zircon dating of volcanic rocks, close to the Silurian-Devonian boundary, from Vendée (western France). Isot. Geosci. 5, 133-142.

Pidgeon, R. T. and Aftalion, M. (1978) Cogenetic and inherited zircon $\mathrm{U}-\mathrm{Pb}$ systems in granites: Paleozoic granites of Scotland and England. Crustal Evolution in Northwestern Britain and Ajdacent Regions eds. D. R. Bowes and B. E. Leake (Geol. J. Spec. Issue 10) 183-220.

Pidgeon, R. T. and Johnson, M. R. W. (1974) A comparison of zircon $\mathrm{U}-\mathrm{Pb}$ and whole-rock $\mathrm{Rb}-\mathrm{Sr}$ systems in three phases of the Carn Chuinneag Granite, northern Scotland. Earth Planet. Sci. Lett. 24, 105-112.

Schärer, U. and Allégre, C. J. (1983) The Palung granite (Himalaya); high-resolution U-Pb systematics in zircon and monazite Earth Planet. Sci. Lett. 63, 423-432.

Tatsumoto, M., Knight, R. J. and Allégre, C. J.
(1973) Time differences in the formation of meteorites as determined from the ratio of lead-207 to lead-206. Science 180, 1279-1283.

Ulrych, T. J. (1969) A comment on the concordia method of interpreting whole-rock $\mathrm{U} / \mathrm{Pb}$ ratios. Earth Planet. Sci. Lett. 7, 116-118.

Wetherill, G. S. (1956) Discordant uranium-lead age, I. Trans. Am. Geophys. Union 37, 320-326.

Williams, I. S., Composton, W. and Chappell, B. W. (1983) Zircon and monazite U-Pb systems and the history of I-type magmas, Berridale Batholith, Australia. J. Petrol. 24, 76-97.

Zartman, R. E. and Haines, S. M. (1988) the plumbotectonic model for $\mathrm{Pb}$ isotopic systematics among major terrestrial reservoirs-A case for bidirectional transport. Geochim. Cosmochim. Acta 52, 1327-1339.

Zartman, R. E. and Hermes, O. D. (1987) Archean inheritance in zircon from late Paleozoic granites from the Avalon zone of southeastern New England: an African connection. Earth Planet. Sci. Lett. 82, 305-315.

Zartman, R. E., Kwak, L. M. and Christian, R. P. (1986) Uranium-lead systematics of a mixed zircon population-The Granite at Yale Farm, Berkshire massif, Connectinut. U.S. Geol. Surv. Bull. 1622, 81-98.

Zhai, J.-P. (1985) Origin of the Anlu quartz-syenite belt and associated uranium mineralization. Unpublished Master Thesis, Nanjing University, 213 pp (Chinese).

Zhang, H. (1988) Isotope geochemistry of the Anlu syenite belt and associated uranium deposits in the Lucong area. Unpublished Master Thesis, Beijing Institute of Uranium Geology, $52 \mathrm{pp}$ (Chinese).

Zhang, Z.-M., Liou, J.-G. and Coleman, R. G. (1984) An outline of the plate tectonics of China. Bull. Geol. Soc. Am. 95, 295-311.

Zheng, Y.-F. (1990) A further three-dimensional U$\mathrm{Pb}$ method for solving the two-stage episodic model. Geochem. J. 24, 29-37.

Zhu, H., Zhang, Z., Chen, J.-F. and Chen, D.-G. (1979) Isotopic dating of metamorphic rocks from the Zhangbaling Group, Anhui Province. J. Uni. Sci. Techno. China 9, 158-185 (in Chinese with English abstract).

Zindler, A. and Hart, S. (1986) Chemical geodynamics. Ann. Rev. Earth Planet. Sci. 14, 493571. 